\title{
Yom Kippur Morning
}

\author{
October 11, 1978
}

Rabbi Beerman's Yom Kippur sermon was delivered eleven months after Egyptian president Anwar Sadat came to Jerusalem in a bold gesture of peace and spoke in the Knesset, Israel's parliament, on November 20, 1977. It also came a month after the historic Camp David Accords were signed by Israel and Egypt on September 6, 1978, with the active mediation of US president Jimmy Carter.

In the midst of the euphoria about this historic moment in which the Jewish state and its largest Arab neighbor made peace, Beerman assumed his prophetic voice and issued a cautionary note: over the course of their long history, Jews have not been especially good at either statecraft or making war. Their real excellence-and true callinglay in struggling for "the realization of truth and justice in the fullness of everyday life." Consistent with that theme, Beerman cut through the excitement of the day and focused with laser-like attention on what he saw as the heart of the problem. "Only through peace with the Palestinian people," he declared, "can the final goal of peace be realized." Already during his first visit to Israel in 1947, he apprehended the abiding challenge of how a Jewish majority must deal with an Arab minority. Following 1967, when Israel came to occupy the West Bank and Gaza Strip, the problem became more acute. Beerman never lost his sense of the critical importance of the Palestinian issue throughout his career. He returned to it again and again, seeing its resolution as a measure of "the realization of truth and justice" that was the Jewish vocation.

There is a picture on my desk at home of my father as a very young man. He is dressed in a World War I khaki uniform with a tight-fitting collar, and he is wearing one of those campaign or doughboy hats with a broad brim all around; and he is standing with two other soldiers, one of them his cousin Alex. The photograph 
is of the time when my father served in the United States Army Ambulance Corps. He was stationed in Italy. There are other pictures I used to look at as a boy; they are all in a photo album, which seemed always to be old and which is still in my parents' home. There were even a few colored postcards of places my father visited when he was a soldier. I remember the one I liked best of all and I thought to be most beautiful. It was a picture of the Bay of Kator along the Dalmatian Coast. There were other places he loved to speak of in Montenegro, along the Adriatic, and in Italy itself.

When I was very young, it used to bother me that my father was in the ambulance corps. Playing in the gravel-covered park of the small Pennsylvania town of my early boyhood, where we used to throw stones at each other, hiding behind the large cannons set there, replicas of the war, I wished my father had been in the infantry, a fighting man, not condemned (so it seemed to me) to bring comfort and healing to the wounded. To a small boy, that didn't seem very military at all. Nothing like the 03 Rifle and the big Mauser automatic pistol he had brought home from the war, and which we used to keep in the attic. That automatic was so heavy; as long as it was around I never developed sufficient strength to pull the trigger.

It was some years later, when I first learned about the Great War and began to think about it and raise questions about it, and even much later than that when I first read Hemingway's A Farewell to Arms (Hemingway had also served in the ambulance corps in Italy), it was then that I began to think that if one had to be in such a horrible war, it was a sign of honor not to be among those who killed. I came to understand, also, that my father's military service was really an expression of his basic character, a reflection of ideals and principles which were an integral part of his thought and behavior as a man, of his whole system of values. Compassion for those who were hurt was not something he put on and took off like a uniform, for a temporary period of his life. That was to be a life-long profession of his. Until a year or so ago, he used to spend a day a week helping out at the Veterans Hospital in Long Beach. Caring about the injured, the poor, the lonely, those who labored in the factories and those who stood outside of them in the long depression years, somehow making society a better place for all, and especially for the least of its people, that has always been a passion of my father's. It permeated his business life as well, his treatment of his employees and his customers. It went everywhere with him, and it still does-although today, sporting a patch over one eye, he looks a little like Moshe Dayan, or at least like Moshe Dayan ten or fifteen years from now.

I was very slow to grow when I was a boy, and in some ways I still am. I had to grow a lot in mind and sensitivity to come close to my father's stature. I finally understood that the essence of my father's strength was really the essence of the strength of our people, the Jewish people. For the strength of our people has always been in the power of its spirit and its sensitivity, in the deep commitment to the ideals set in the center of its being, the commitment to act out of love, and to be 
willing to bear the suffering that decent human beings must inevitably bear in a world such as ours. That is the strength that accounted for our tenacity, our fierce determination to live; that is the incredible power within us that made for our survival. Yes, the strength of our people has always been in that power. Some of us have been able to learn that from our parents. I have. Some of us are teaching it to our children. I hope you are.

Oh, I know that through most of our history we Jews have done a lot of fighting and struggling. But our greatest struggles, as Heine once said, were on the battlefield of human thought. It was there, in the realm of spiritual warfare, in that relentless restlessness of our people's spirit, it was there [that] we won our great medals, it was there [that] we found our greatest greatness.

For very early there had entered into our people's spirit a ferment that would give it no rest. In the midst of the pagan world, so magnificent in the grandeur of its material achievement, one people questioned what was universally accepted by those who lorded their power and their majesty over them. When all about them the great nations of the world worshipped gods of stone and mountain, one people alone refused. For this people had come to believe of itself that it had been called to prepare this earth as a kingdom for God through the realization of justice. That just as there was the One who "had set the sun in the sky," Buber taught us, "so did they believe that there was a Lord of being and coming to be who had set a commandment of truth and justice above the heads of the human race." The great duty set before our people was the realization of truth and justice in the fullness of everyday life.

This command, this expectation, has always been difficult, too difficult for our people. It always set upon us the painful requirement that we be different, that we seek a special dignity, a special refinement, that we separate ourselves from the manners and the values of the nations amongst whom we lived, where those values violated the essential principle of our civilization. The way was too hard, and from the earliest times our people rebelled against it. They preferred a visible god to the invisible One of whom Moses taught them. They were forever to be seduced by the idols of power and wealth, of comfort and ease. The Bible describes in excruciating detail how this happened, what cruel punishments were visited upon the people, culminating in their destruction and exile. But not only the Bible, the whole of Jewish history is a record of struggle against all those forces, within and without, that would divert a people from the truth of its being, from the essential principle of its civilization, which is, I repeat, the realization of truth and justice in the fullness of everyday life.

The same forces beset us today, only this time more powerful, more seductive than ever before. But I believe the strength of our people to reckon with those forces is still in the power of its spirit, in its capacity to act out of love on behalf of the ideals set in the center of our being.

I am very much aware that I speak these words on the fifth anniversary of the Yom Kippur war, and in the thirtieth year of the establishment of the State of 
Israel-a reminder not only of the incredible achievements of Israel but also of its remarkable military accomplishments as well, the tremendous courage it has displayed in its wars of survival.

It may be uncomfortable to remember, but surely it is well known to all of you, that from the most ancient times the Jewish people has demonstrated no particular gifts at making war. Nor have we been particularly good at maintaining a nation. None of the battles of our ancestors, the ancient Israelites, has ever been recorded in military annals. Great military geniuses we have never produced. Before the mighty armies of the ancient Near East, Israel always fell to defeat: Assyria, Babylonia, Egypt, the Greeks, the Romans-it was always the same story. In works of fiction, we won military victories. In the Book of Esther, which we read every Purim, although we carefully manage to skip this part of it-there we are able to slay 75,00o Persians, and glory in it. The Maccabees had a brief experience of victory over the Syrian Greeks, but the independence they achieved quickly gave way to inner Jewish corruption; soon, Jews were once again a subject people.

Israel became what it was to be for most of its history as a national entity, and what it is today-a vassal state, dominated always by someone else's purposes. So we were to Greece and even to Rome, until Rome became impatient with the rebelliousness and the pretensions to power of the Jewish zealots, mystical hooligans. So the Romans finally did to the Jews what they could have done at any time-they destroyed the Temple; they destroyed the nation. Yet our people lived on because the rabbis of that time helped them understand that the foundation of their being as a people was not in a cult centered in a temple, but in something sacred to be realized in the fullness of their everyday life. If they could hallow themselves and their lives, they could outlive any conqueror. And so they did.

Yet it has been our historic fate to dwell always in the shadow of the power of others. So it was then; so it is today, for Israel, for Jews everywhere. It is in the light of this uncomfortable truth that we consider the events which have culminated in the dramatic achievement at Camp David.

Eleven months ago I was in Jerusalem, dancing in the street with the crowd gathered there, as I saw President Sadat enter the King David Hotel. The next day, along with every Israeli and millions of people throughout the world I heard the leader of Egypt, the most powerful Arab nation, speak these words: "You want to live with us in this part of the world. In all sincerity I tell you we welcome you among us with full security and safety. What is peace for Israel? It means that Israel lives in the region with her Arab neighbors in security and safety. To such logic, I say yes. It means that Israel lives within her borders, secure against any aggression. To such logic, I say yes. It means for Israel all kinds of guarantees that insure these two factors. To this demand, I say yes."

With this dramatic and courageous initiative, unparalleled in diplomatic history, the Egyptian president at great personal danger changed the situation in the Middle East, made a total break with Arab policies of the past thirty years, a break 
with that deeply imbedded rejection of Israel's right to exist as a sovereign nation ("No negotiation, no recognition, no reconciliation"). ${ }^{1}$ It was clear that Egypt was determined to achieve peace even at the terrible risk of a deep rift in the Arab world. It seemed so certain that a peace settlement was within reach, and that it could be a real peace in the full meaning of the word, not just a truce between opposing nations growling fiercely at each other.

So I wanted to believe last November, and so I did. Here was an opportunity to put an end to the conflict that had brought untold misery and bloodshed-the terrible waste of life, resources - the mental anguish. I was overwhelmed by the euphoria of that moment, grateful that I could have been in that place in that historic time. Thirty years before that November, in November 1947, Martha and I had been in the same Jerusalem rejoicing at the news that had come from Lake Success in New York, announcing that the United Nations had voted to partition Palestine into two states: One Jewish, One Arab. That decision permitted Israel to come into being six months later, in May of 1948. But the joy of November 1947 gave way to the fierce and terrible events of Israel's War of Independence. Would the joy of November 1977 vanish as quickly as it had come into being? Such, unfortunately, was to be the case. The drama of November, the exchange of visits, the ecstasy that swept over Egyptians and Israelis soon gave way to a war of words and a new gloom.

We have been rescued from that gloom because the President of the United States and his advisors seized the initiative, indicated to both parties what they thought was right for the Middle East, invited Egypt and Israel to Camp David to negotiate based on this plan, and then provided the necessary "nudging" to help bring about the agreement.

For the central factor in the Middle East since 1973 has been the emergence of the United States as the dominant power in the region. As Professor Stanley Hoffman of Harvard's Center for European Studies has pointed out, and it is his words I now bring to you, our country is now involved in a complex web of relationships in the Middle East. America is engaged with its Arab clients, especially Saudi-Arabia, in a relationship such that it is sometimes difficult to determine who is the real client, who manipulates whom. We need the oil; they need our weapons and technology. We want them to turn to us rather than to the Europeans or the Japanese, to invest their money in the United States, to keep OPEC from raising oil prices to levels our allies and many developing nations could not afford, to cooperate with us in managing an increasingly acrobatic world financial system. United States policy now has two imperatives, Professor Hoffman argues: Arab power must be used in ways favorable to American interests. There must be no war between the Arabs and Israel, since such a war would present America with impossible choices and could provoke new strains between the United States, Western Europe, and Japan.

The second imperative is for a movement toward a settlement of the Arab-Israeli conflict, for a settlement of the Arab-Israeli conflict is the only way to maintain 
American dominance in the area and to prevent a new Soviet penetration into the area. The Arab-Israeli conflict is therefore obsolete, from the American point of view; it is an obstacle to the pursuit of the long-range interests of all the parties. A peace settlement, Professor Hoffman insists, is absolutely imperative for the United States and for Israel and the Arab states, the nations within the American orbit of influence.

The achievement at Camp David is a tribute to all of the participants in it, and surely to the reason and the flexibility demonstrated by President Sadat and Prime Minister Begin. Still it must be remembered that peace has not been accomplished, but only a framework within which peace can be achieved. The agreement is very fragile. It leaves so very much to be thrashed out. And it is fraught with areas of danger, and the areas of danger are precisely the areas of the agreement that are vague.

The agreement is particularly vague with regard to what lies at the very heart of the Israeli-Arab conflict - the problem of the Palestinians and the future of the West Bank. Only through peace with the Palestinian people can the final goal of peace be realized; only through a generous and respectful recognition of the right of the Palestinians to define themselves, their identity, to have their sovereignty over the portion of Palestine promised to them and agreed to by every Israeli government, prior to this one, and not to have a definition imposed upon them by the PLO, by Jordan, by the Israelis, by anyone but themselves-only thus can there be peace.

Whoever would still deny to Israel or the Palestinian Arabs the right to build a life of their own is an enemy of peace. Within the Arab world, the PLO and the so-called radical Arab states are still sworn to war. But among Jews there are those who are enemies of peace and security as well. Those religious zealots who claim the land by divine mandate, whose battle cry is "not an inch," "all or nothing," are a grave danger to the hope for peace. Wherever they are, they are as dangerous to life and to Israel as their equivalents among the Arab rejectionists and terrorists. Those who advocate more settlements on the West Bank are in the same category.

As for us American Jews, it is time for us to seize the hope engendered at Camp David and to join the peacemakers; to open our minds and hearts to the justice due our enemies. And to join those tiny forces in the world that insist that the continued reliance on military power is an ill-breeding of the mind that perverts every possibility for the ennoblement of the human enterprise.

And it is time for us, long overdue, to think seriously again about the quality of our lives as American Jews, for the quality of our lives has suffered immeasurably because of the mentality of being under siege, a mentality which has held us captive over these thirty years. Our sense of perspective has become totally distorted. A single anti-Semite opens his stupid mouth and ten thousand American Jews summon up images of a new holocaust. The spectacle of 5,000 Jews in Chicago, marching in protest before twenty-six puny American Nazis, is a symbol of the idiocy to which otherwise intelligent people can descend. The hyperventilated 
response to the Scheer articles is of the same order. ${ }^{2}$ There is a great deal about us Jews that calls for celebration, and there is much about us for which we should be ashamed, not the least of which is our exaggerated self-pity and self-righteousness, the rising cultic tribalism-and a new phenomenon-the Jewish Archie Bunkers among us, only nobody is laughing.

There is much work of healing that needs to be done, to bind up our wounds, to renew the vision of our true strength, to take up again the ideals set in the center of our people's being. For that is our strength, that is our power. Wherever we act out of love to help diminish the store of human anguish, we assert our power as Jews ... but this is another sermon, one that will be continued throughout the year.

Do the children still play in the gravel-covered park of my birthplace? Do the boys throw stones, hiding behind the cannons set there, replicas of my father's war? Do they imagine their fathers brave in battle, wielding their rifles and bayonets and pistols? Will they grow to be strong in their power, to be tender human beings, loving themselves, loving life, nurturing it?

"See I have set before thee this day life and death and blessing and curse, therefore choose life, that thou mayest live."

\section{COMMENTARY BY MILTON VIORST}

Leonard Beerman delivered this sermon barely a decade after the Six-Day War, and five years after the Yom Kippur War, which together transformed Israel's relationship with its Arab neighbors and the international community. It was a lament for where he perceived Israel was heading. His warning did not make him more popular among his congregants, but Leonard was always more committed to truth than to popularity. Since then, the Arab-Israeli conflict has grown more heated, global society more remote, prospects for peace more elusive. Today Leonard's sermon of four decades ago is no less relevant, and were he with us, he could deliver it again.

In the sermon, Leonard lauds the refusal of the early Jews to follow the era's great powers in worshipping the gods of stone and mountain, seeking instead to establish a kingdom of God through the realization of social justice. It was a severe challenge, which many Jews found too difficult to embrace. It did not, furthermore, endear the Jews to the peoples among whom they lived, and over the centuries they paid heavily for their differences. When Herzl founded Zionism as a refuge from the pains inflicted on them by their enemies, Vienna's Chief Rabbi implored him to beware that a Jewish state built on cannons and bayonets risked emulating Europe's warrior powers. Herzl scoffed, but time, vindicating the rabbi's admonition, has seriously deformed Herzl's dream.

I came to know Leonard because we both believed Jews could best be served by giving their allegiance to another, more humane Zionism. He alluded to it not just in this, but in nearly all his sermons. It is a cause for which he will long be remembered. I am proud to have been his friend. 